J. Clin. Chem. Clin. Biochem.

Vol. 16, 1978, pp. 387-389

\title{
Radioimmunoassay and Automated Enzyme Immunoassay for the Determination of Thyroxine
}

\author{
By W. F. Riesen, Bojana Muacevic and Martha Jaggi \\ Central Laboratory, Tiefenauspital and Institute for Clinical \& Experimental Tumour Research of the University of \\ Berne, Tiefenauspital, CH-3004 Berne, Switzerland
}

(Received January 20, 1978)

\begin{abstract}
Summary: The EMIT homogeneous enzyme immunoassay for the determination of thyroxine $\left(\mathrm{T}_{4}\right)$ was adapted to an automatic analyser (Type Kem-O-Mat) and compared with a conventional radioimmunoassay. Sera from 92 patients whose thyrometabolic status was being examined, and control sera with 3 different $T_{4}$ concentrations were analysed by both methods. Day-to-day analyses of the control sera gave variation coefficients between 6 and $10 \%$ for both methods. The mean value for $\mathrm{T}_{4}$ in the patients sera was $111 \mathrm{nmol} / 1(8.6 \mu \mathrm{g} / \mathrm{dl})$ determined by the enzyme immunoassay and $109 \mathrm{nmol} / 1(8.5 \mu \mathrm{g} / \mathrm{dl})$ determined by the radioimmunoassay; the correlation coefficient was $\mathrm{r}=0.9$.
\end{abstract}

\section{Vergleich von automatisiertem Enzym-Immunoassay und Radio-Immunoassay zur Bestimmung von Thyroxin}

Zusammenfassung: Der homogene EMIT Enzym-Immunoassay für die Bestimmung von Thyroxin $\left(\mathrm{T}_{4}\right)$ wurde auf einen automatischen Analysator (Kem-O-Mat) adaptiert und mit einem konventionellen Radio-Immunoassay verglichen. Seren von 92 Patienten, deren Schilddrüsenfunktion untersucht wurde, und Kontrollseren mit 3 verschiedenen $\mathrm{T}_{4}$-Konzentrationen wurden mit beiden Methoden auf ihren $\mathrm{T}_{\mathbf{4}}$-Gehalt geprüft. Von Tag zu Tag Analysen der Kontrollseren ergaben Variationskoeffizienten zwischen 6 und $10 \%$ bei beiden Methoden. Der Mittelwert für $\mathrm{T}_{4}$ in den Patientenseren betrug $111 \mathrm{nmol} / 1(8,6 \mu \mathrm{g} / \mathrm{dl})$ beim Enzym-Immunoassay und $109 \mathrm{nmol} / 1(8,5 \mu \mathrm{g} / \mathrm{dl})$ beim Radio-Immunoassay. Der Korrelationskoeffizient war $r=0,9$.

\section{Introduction}

The evaluation of thyroid function is still a very complex matter although a considerable number of testing methodologies have been developed (1). At the present time, however, there seems to be general agreement that the optimum first step in evaluating a patient with a thyroid problem is to measure the concentration of the total thyroxine $\left(\mathrm{T}_{\mathbf{4}}\right)$ in serum.

Today this is most commonly done by a radioimmunoassay (2). The development of a homogeneous enzyme immunoassay $(3,4)$ which is now also commercially available for $\mathrm{T}_{4}$, gives the performance characteristics of an immunoassay without the disadvantage of radioactive reagents. In addition the homogeneous enzyme immunoassay lends itself for adaption to automatic analysers.

The objective of this study was to compare the quantitative results obtained for $T_{4}$ by a radioimmunoassay with those obtained by the EMIT enzyme immunoassay, which was adapted to a programmable analyser.

\section{Material and Methods}

Serum samples were obtained from patients whose thyrometabolic status was being studied. Each sample was analysed by both enżyme immunoassay and radioimmunoassay.

The reagents for the EMIT enzyme immunoassay of thyroxine were from Syva Corp., Palo Alto, obtained through the courtesy of Merck Diagnostica (Darmstadt). They were adapted to a programmable, fully automatic analyser (KemO-Mat, Coulter, England) for which a special program for thyroxine was devised. Reagent volumes, incubation and reaction times were in accordance with the manufacturer's suggestions.

The radioimmunoassay test kit was purchased from Diagnostic Corporation (Los Angeles). This was a double antibody assay employing [ ${ }^{125} \mathrm{IJT}_{4}$ as tracer, rabbit anti- $\mathrm{T}_{4}$ antibody and goat anti-rabbit gammaglobulin.

TRI-rac control sera were from Merz \& Dade, (Düdingen, Switzerland). They contained 55, 122 and $219 \mathrm{nmol} / 1$ (4.3, 9.5 and $17.0 \mu \mathrm{g} / \mathrm{dl}) \mathrm{T}_{4}$.

\section{Statistical analysis}

The statistical comparison of the concentrations of $T_{4}$ found by enzyme immunoassay and by radioimmunoassay was done from 
the least-squares parameters (slope of the least-squares line, $y$ intercept, standard error of estimates) as recommended by Westgard \& Hunt (5).

\section{Results}

\section{Patients' sera}

The statistical comparison of the 92 patients' sera which were assayed for $\mathrm{T}_{4}$ by EMIT immunoassay and radioimmunoassay is given in table 1 and figure 1 . The slope of the line is 0.91 , which indicates proportional error

Tab. 1. Statistical comparison of radioimmunoassay and EMIT enzyme immunoassay for thyroxine $\left(\mathrm{T}_{4}\right)$.

\begin{tabular}{|c|c|}
\hline Number of samples & 93 \\
\hline Correlation coefficient & 0.90 \\
\hline Slope of least-squares regression line & 0.91 \\
\hline $\begin{array}{l}\text { Intercept of least-squares regression line } \\
\mathrm{nmol} / \mathrm{l}(\mu \mathrm{g} / \mathrm{dl})\end{array}$ & $10.56(0.82$ \\
\hline $\begin{array}{l}\text { Standard error of the estimate, sxy } \\
\text { nmol/l }(\mu \mathrm{g} / \mathrm{dl}) \\
\text { Mean }\end{array}$ & $36.07(2.8)$ \\
\hline $\begin{array}{l}\text { EMIT enzyme immunoassay } \mathrm{nmol} / \mathrm{l}(\mu \mathrm{g} / \mathrm{dl}) \\
\text { Radioimmunoassay } \mathrm{nmol} / \mathrm{l}(\mu \mathrm{g} / \mathrm{dl})\end{array}$ & $\begin{array}{l}(8.6) \\
(8.5)\end{array}$ \\
\hline
\end{tabular}

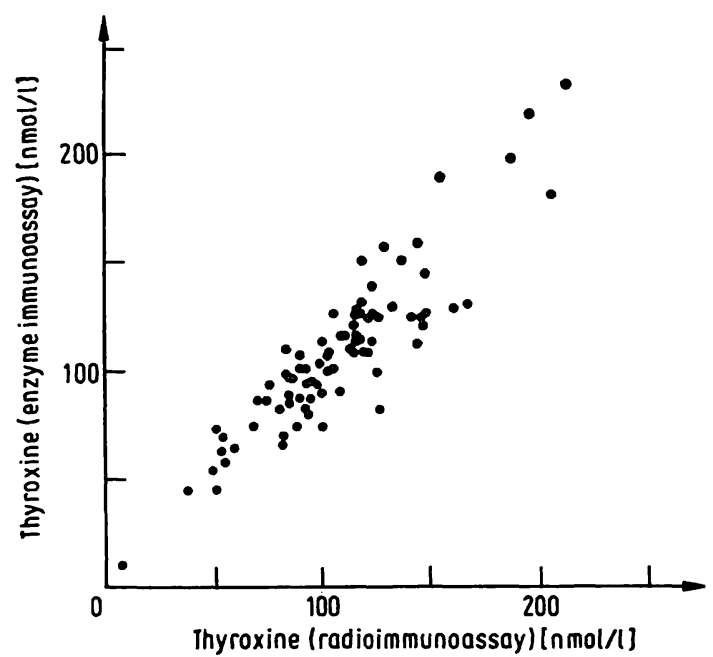

Fig. 1. EMIT enzyme immunoassay vs. radioimmunoassay (RIA) compared for thyroxine $\left(\mathrm{T}_{4}\right)$ determination. less than $9 \%$. Constant error is estimated at $10.56 \mathrm{nmol} / 1$ $(0.82 \mu \mathrm{g} / \mathrm{dl})$ from the intercept of the ordinate. Random error is estimated at $36.07 \mathrm{nmol} / 1(2.8 \mu \mathrm{g} / \mathrm{d} l)$ from the standard error of the estimate, $s_{x y}$.

\section{Controls}

TRI-rac control sera containing 55, 122 and $219 \mathrm{nmol} / 1$ $(4.3,9.5$ and $17.0 \mu \mathrm{g} / \mathrm{dl})$ were assayed on $1.0 \mathrm{different}$ days. $\mathrm{T}_{4}$ concentrations obtained were used to calculate standard deviations and coefficients of variation for both methods (see tab. 2). Coefficients of variation for the EMIT enzyme immunoasssay were 10.7 and $6 \%$, for the radioimmunoassay they were 8.8 and $6 \%$. The average values were all within the manufacturer's predicted range. The precision of the EMIT enzyme immunoassay within series was tested by serial analysis of 2 control sera containing 122 and $219 \mathrm{nmol} / \mathrm{l}(9.5$ and $17.0 \mu \mathrm{g} / \mathrm{dl})$ $\mathrm{T}_{4}$ (tab. 3). The coefficients of variation were 3 and $4 \%$ respectively.

\section{Discussion}

This study presents randomized comparative data on the merit of a homogeneous enzyme immunoassay (EMIT) for the determination of thyroxine $\left(T_{4}\right)$ versus a conventional radioimmunoassay. The enzyme immunoassay was adapted to a Kem-O-Mat programmable analyser which is capable of performing automated UV enzyme kinetic determinations, as well as end point chemistries. This analyser has two different dispenser units and the EMIT $\mathrm{T}_{4}$ immunoassay can therefore be performed without any extra installation. The first step is manual and it involves the addition of a sodium hydroxide-containing solution (Liplex) to the samples, in order to free protein bound $\mathrm{T}_{4}$ molecules, separate fatty acids and destroy interfering proteins. All further steps were performed automatically by the analyser according to a program specially devised for the EMIT $\ddot{\mathrm{T}}_{4}$ enzyme immunoassay. Besides the

Tab. 2. Day-to-day analysis of $T_{4}$ in control sera by EMIT enzyme immunoassay and radioimmunoassay.

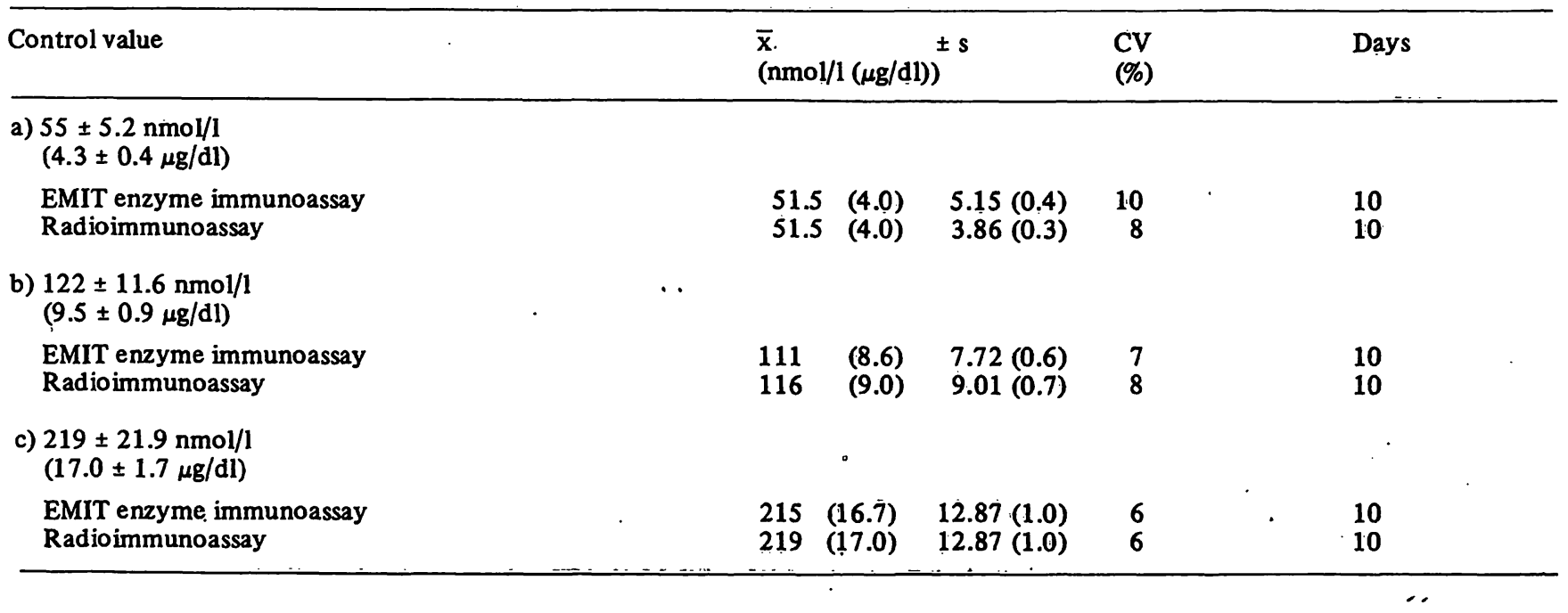


Tab. 3. Within-day analysis of $T_{4}$ in control sera by the EMIT enzyme immunoassay.

\begin{tabular}{|c|c|c|c|c|}
\hline Control value & $\begin{array}{l}\bar{x} \\
(\mathrm{nmol} / \mathrm{l}(\mu \mathrm{g})\end{array}$ & $\pm s$ & $\begin{array}{l}\text { CV } \\
\%\end{array}$ & $\mathbf{n}$ \\
\hline $\begin{array}{l}122 \pm 11.6 \mathrm{nmol} / 1(9.5 \pm 0.9 \mu \mathrm{g} / \mathrm{dl}) \\
219 \pm 21.9 \mathrm{nmol} / 1(17.0 \pm 1.7 \mu \mathrm{g} / \mathrm{dl})\end{array}$ & $\begin{array}{l}111(8.6) \\
215(16.7)\end{array}$ & $\begin{array}{l}3.86(0.3) \\
9.01(0.7)\end{array}$ & $\begin{array}{l}3 \\
4\end{array}$ & $\begin{array}{l}17 \\
10\end{array}$ \\
\hline
\end{tabular}

convenience of automation, this method also saves a considerable amount of time. The analysis time for 32 samples, which is the maximum number of samples which may be run at one time, was 15 minutes. The preincubation with Liplex needs another 15 minutes. In contrast, the time required for the assay of comparable number of samples by the radioimmunoassay averaged about 1.5 hours. Counting times were not included.

Both EMIT enzyme immunoassay and radioimmunoassay showed satisfactory precision. Day-to-day analysis of control sera with 3 different concentrations gave variation coefficients between 6 and 10\%. Withinday analysis was only performed for the enzyme immunoassay and showed fair precision (variation coefficients $4 \%$ and less).

In addition to control sera, specimens from 92 patients whose thyrometabolic status was being examined were compared by both methods. The mean value for $T_{4}$ in these sera obtained by the EMIT enzyme immunoassay $(111 \mathrm{nmol} / 1=8.6 \mu \mathrm{g} / \mathrm{dl})$ correlated well with the mean value obtained by the radioimmunoassay $(109 \mathrm{nmol} / 1$ $=8.5 \mu \mathrm{g} / \mathrm{dl})$. The good correlation between the two methods is further substantiated by the correlation coefficient of 0.9 and the slope of the least-squares regression line of 0.91 .

In view of these data, substitution of the radioimmunoassay for $\mathrm{T}_{\mathbf{4}}$ by the EMIT enzyme immunoassay would not require any change in currently used normal values.

\section{Acknowledgements}

The authors are indebted to Mr. H. U. Meier, Instrumentengesellschaft, Zürich, for help with the program for the Kem-OMat an to Mr. G. F. Cavallini (Merck, Diagnostica) for providing the EMIT enzyme immunoassay test kit. W.F.R. was supported by a grant from the Swiss National Science Foundation.

\section{References}

1. Pain, R. W. (1975), Pathology 7, 1-12.

2. Chopra, I. J., Solomon, D. H. \& Ho, R. S. (1971) J. Clin.

Endocrinol. Metab. 33, 865-866.

3. Rubenstein, K. E., Schneider, R. S. \& Ullmann, E. F. (1972), Biochim. Biophys. Res. Commun. 47, 846-851.

4. Bastiani, R. J., Phillips, R. C. \& Schneider, R. S. (1973), Amer. J. Med. Tech. 39, 211-216.

5. Westgard, J. O. \& Hunt, M. R. (1975), Clin. Chem. 19, 49.

PD Dr. W. F. Riesen,

Institut für klinisch-experimentelle Tumorforschung der Universität Bern,

Tiefenauspital,

CH-3004 Bern/Schweiz 
.

$\cdots$

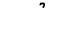

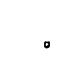

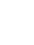

$\because$

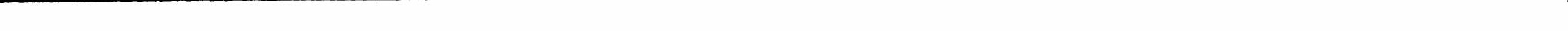

(1)

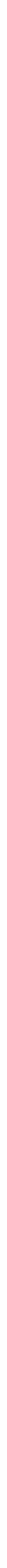

